\title{
O CORPO FEMININO E SEUS ENIGMAS: A ESFINGE NA PINTURA DE FRANZ STUCK
}

\author{
Enéias Farias Tavares \\ Universidade Federal de Santa Maria \\ Santa Maria, RS, BR.
}

\section{Resumo}

Neste ensaio, discutirei o problema da representação do feminino nas artes do final do século XIX. Para tanto, partirei da leitura de Bram Dijkstra em Idols of Perversity (1986). Na sequência, refletirei sobre o modo como o imaginário do corpo feminino está associado ao encontro de Édipo e a Esfinge, monstro feminino que oferta enigmas e apresenta uma composição corporal tripartida. O estereótipo desse feminino demonizado, todavia, começa a ser repensado no mesmo século, tornando-se a própria figuração da esfinge um enigma a ser pesquisado. Minha análise para a leitura dessa alteração de sensibilidade nas artes no período centrar-se-á em três pinturas do artista alemão Franz Stuck para o tema da Esfinge. Para tanto, dialogarei com as reflexões de Connell, Edmunds, Paglia e Goex, além das de Dijkstra.

Palavras-Chave: Corpo feminino; pintura; literatura; esfinge.

\section{THE FEMALE BODY AND ITS ENIGMAS: THE SPHINX IN FRANZ STUCK'S PAINTING}

\begin{abstract}
This essay discusses the problem of female representation in the arts at the end of the nineteenth century. Therefore, I will start from a reading Bram Dijkstra's Idols of Perversity (1986). Following, I will reflect on how female body imagery is associated with the meeting of Oedipus and the Sphinx, female monster that offers puzzles and presents a hybrid body configuration. The stereotype of this demonized woman, however, begins to be rethought in the same century, becoming the Sphinx itself and its corporeal constitution a puzzle to be researched. My analysis for reading this change in sensitivity in Western arts will focus on three different paintings by the German artist Franz Stuck on the theme of the Sphinx. Therefore, I will use, besides Dijkstra, reflections by Connell, Edmunds, Paglia and Goex.
\end{abstract}

Keywords: Female body; painting; literature; Sphinx.

\section{I}

O corpo feminino e seus mistérios. A voz feminina e seus enigmas. A imagem feminina e seus perigos. Desde que Homero alocou em sua Odisseia - que ao lado da Ilíada formam os pilares iniciais da cultura literária ocidental - uma série de figuras femininas se- dutoras quando não monstruosas, atraentes senão perversas, maternais e também assassinas, o problema da representação do corpo feminino se mostra central à cultura do ocidente.

$\mathrm{Na}$ Odisseia, Agamêmnon no inferno adverte sobre não confiar nas mulheres, vide sua esposa criminosa Clitemestra. Ulisses enlouquece ao ouvir os 
cantos das sereias monstruosas. Circe oferta pão e vinho, além de seus outros encantos, como engodo para transmutar homens em suínos. Associados à Gaia e a uma natureza desconhecida e terrível, Cilas e Caribdes, monstros também femininos, despedaçam tanto homens quanto embarcações.

No decorrer do tempo, aprendemos a identificar alguns desses relatos como comprovação de uma misoginia que perpassaria a história do ocidente, repúdio ao feminino presente não apenas na cultura clássica - vide as nefastas advertências de Hesíodo contra a descendência de Pandora em Os Trabalhos e os Dias - como também na cultura judaico-cristã, em sua apresentação nada favorável das filhas de Eva. Nela, são mulheres como Judite, Dalila e Salomé, entre tantas outras, que não apenas desgraçam piedosos heróis masculinos, quando não decepam suas cabeças. Se isso não é inteiramente verdade no caso de Holofernes e Judite, o é no caso de Sansão e João Batista.

Em Idols of Perversity - Fantasies of Feminine Evil in Fin-De-Siecle Culture (1986), Bram Dijkstra elabora um primoroso estudo a respeito das várias dimensões do feminino no que concerne à sua origem mítico-literária, como, em especial, a forma como tais figuras marcaram o imaginário pictórico e estético de pintores, críticos e comerciantes de arte na Europa do século XIX, num pano de fundo que formaria, décadas mais tarde, a cama sobre a qual a psicanálise, ao estudar o feminino histérico, estenderia seus lençóis conceituais e interpretativos.

Sua meta é detalhar essa "Iconografia da Misoginia”, por contrastar obras visuais com artefatos literários, num mosaico que poderíamos denominar de "textualidade de misoginia" ou de "poéticas da angústia masculina”. Ora são mulheres inquietantes, malignas, fatais, sedutoras e mortíferas, o que encontramos na Comédia Humana de Balzac, nas flores lésbicas de Baudelaire, nas visões de Huysmans em Às Avessas, na destruição de Sybil Vane em Dorian Gray e na lunar Salomé de Wilde, entre tantas outras obras que constituem o corpus da arte fin-de-siecle. Para tanto, Dijkstra reflete sobre três grandes grupos representacionais desta visão - essencialmente masculina e patriarcal - do feminino.

Num primeiro momento, Dijkstra discute figuras femininas passivas, moribundas, frágeis, doentias e fantasmáticas, como virgens puras e tuberculosas ou mulheres velhas e decrépitas. Esta "iconografia da freira doméstica" remete sempre à Virgem Maria ou a um pictórico "culto da invalidez feminina" (1986, p. 28), como as inúmeras representações de Ofélia atestam. Neste caso, são mulheres passivas, frágeis, doentias, que não demandam nenhum tipo de investimento libidinal ou erótico. Nelas e perto delas, o gênero masculino resulta forte, soberano, auto-centrado e integral. Talvez o apelo de tais imagens esteja justamente nessa dimensão, uma vez que são pinturas masculinas direcionadas a um público consumidor e comprador essencialmente masculino. ${ }^{1}$

Como Dijkstra deixa claro, colocar o feminino "neste gigantesco pedestal de virtude" virginal e decadente não passaria de uma "fantasia masculina de poder absoluto, de controle absoluto - tendo o mundo rastejando aos seus pés" (1986, p. 19). Para tais defensores da moralidade e dos costumes familiares tradicionais, a imagem de um feminino doentio, frágil e absolutamente santificado, ou seja, mortificado na carne por um espírito obcecado pela santidade do corpo, era mais do que aceitável. Talvez, até perfidamente desejável:

\begin{abstract}
Assim, aquilo que o macho da metade do século desejava, acima de tudo, era uma mulher que não apenas deveria ser a salvadora de sua alma, mas que poderia também, na verdade, ofertar o seu próprio ser, a sua completa alma a esta tarefa, uma mulher que poderia se tornar uma extensão de si próprio, que se deixaria ser totalmente absorvida por ele. (1986, p. 20)
\end{abstract}

Todavia, como Dijkstra conclui, "ao invés de aprenderem o recolhimento e a morte como resposta de um século inteiro de doutrinação, as mulheres pareceram mais e mais determinadas a resistir e lutar, a serem ouvidas. E a sexualidade uma vez mais insistiu em levantar sua cabeça bestial" (1986, p. 63). É nesta resistência indireta, muitas vezes exemplificada por vozes masculinas, que encontramos a re-ativação do oposto dessas mulheres santificadas: são Dalilas, Salomés, Esfinges, Medusas, Sereias e Judites, que corporificarão uma contra-resposta ao ideário da santidade e do confinamento domésticos. 
Além deste contraste, há dois outros grupos imagísticos que nos interessam a fim de compreender o feminino nas artes no período. Primeiro, há um esforço de afastar essas personagens de seu contexto familiar/ doméstico, reproduzindo a outra aporia - presente, mais uma vez, desde Homero e explicitada pelas Bacantes de Eurípides e a fuga das mulheres da cidade de Tebas -, a de que as mulheres estariam conectadas à natureza e a forças ctônicas, conexão a duras penas mal compreendida pelos homens, que o diga o despedaçado Penteu. ${ }^{2}$

Num terceiro grupo, os poetas e artistas finisseculares também evidenciarão fascínio pela capacidade dessas "criaturas" apresentarem uma voz e poderem se comunicar com os heróis que as enfrentam. O absurdo da frase anterior fica evidente quando olhamos pinturas de Esfinges, Medusas, Mênades, Sereias e outras, que estão interessadas em expressar uma interioridade por meio da fala, mesmo que esta seja apenas na forma de um grito de horror e pavor. ${ }^{3}$ Dijkstra, ao refletir sobre esse imaginário e ao resumir a tese de seu livro, afirma que

por volta de 1900, escritores e artistas, cientistas e críticos, cultos e também leigos, tinham sido doutrinados a julgar todas as mulheres que não mais se conformavam à imagem de freiras domésticas como criaturas bestiais e viciosas, representativas de um passado pré-evolutivo e instintivo, que preferiam a companhia de animais a dos homens civilizados, criaturas que eram, na verdade, a personificação da bruxaria e da malignidade, frequentadoras de Sabás e de rituais perigosos, montadas em bodes, como o pintor espanhol Louis Falero, entre outros, as representou. A mulher, em resumo, veio a ser vista como uma deusa monstruosa da degeneração, uma criatura maligna que dominava sobre todas as bestas chifrudas que povoava os pesadelos sexuais masculinos. (1986, p. 325)

O sumário de Idols of Perversety ilustra a progressão de uma representação do feminino calcado em elementos positivos e religiosos que gradativamente degeneram no absoluto monstruoso. São Freiras Domésticas, Damas Florais e Vítimas Agonizantes que pouco a pouco vão dando lugar a jovens esgotadas, ninfas flutuantes, heroínas ctônicas, amantes lunares, narcísicas e lés- bicas, amantes dependentes e disponíveis, suplicando por "estupros terapêuticos", flores venenosas ilustradas por mênades, sereias, górgonas, bruxas, vampiras virginais e prostitutas castradoras, num caleidoscópio imagético e literário que diagnostica o sórdido "imaginário misógino" do mundo ocidental.

Por um lado, tal recorte reforça uma percepção preconceituosa e perversa - que associa o feminino ao monstruoso natural, ao perigoso mundo das diabruras divinas e à incapacidade do homem de dominar e domesticar um entorno natural/feminino. Por outro, há uma tentativa por parte de artistas e também de poetas e romancistas, de articular uma dimensão mais complexa e atraente ao olhar moderno - no sentido de ponderar e refletir, quando não de representar, uma interioridade que, além de ser complexa e profunda, tenta estabelecer um canal de comunicação. Esse mutismo que agora ganha os traços dos gritos das bacantes e dos diálogos de Circe evidencia a gradativa percepção - tão cara ao século passado e ao nosso - do corpo e de sua materialidade. A partir dessa constatação, percebe-se que nenhum mito constitui da antiguidade ao presente um conjunto tão rico de filamentos simbólicos como o da Esfinge que guarda os portões de Tebas à espera de um herói capaz de desvendar-lhe os enigmas.

\section{II}

A Esfinge pertence ao rico elenco de monstros femininos caros à cultura grega. Ao lado de Sereias e Górgonas, Bacantes e Fúrias, ela encerra um hibridismo que conecta o humano ao mundo natural e selvagem. Prima distante de sereias enlouquecedoras e górgonas petrificantes, ela possui corpo leonino, asas de águia, cauda de serpente e seios e face de virgem. Este aspecto híbrido já articula na cultura um importante paradoxo.

Por ser conhecida como uma criatura que propõe enigmas numa linguagem reconhecível ao homem, a Esfinge parece articular um estágio posterior da relação deste com o ambiente natural, uma relação perpassada pela e na linguagem. Todavia, intérpretes tradicionais têm insistido em seguir trilha oposta a ela, ignorando a comunicação entre o herói e o monstro. Seu corpo híbrido e seu enigma sobre um animal que vai mudan- 
do de acordo com sua locomoção têm raramente sido mencionados para aludir a este elemento.

Nessa acepção, a esfinge figuraria um período intermediário no qual a sociedade humana estaria ainda próxima de uma não distinção entre o cultural e o natural, ao passo que herói que lhe desvenda o enigma encenaria a distinção entre o humano e o animal, entre o cultural e o natural, entre a inteligência e o instinto. Essa leitura da Esfinge como mito intermediário entre as religiões naturais - perceptíveis, por exemplo, na versão egípcia da Esfinge - e as religiões da individualidade espiritual foi proposta por Hegel em Lições sobre a Filosofia da Religião. ${ }^{4}$

Hegel e muitos de seus leitores posteriores interpretaram a Esfinge como símbolo de um mundo ainda primitivo no qual o homem não se via completamente apartado da natureza. Porém, associar a Esfinge unicamente ao elemento natural ou à comunicação dela com Édipo como contraste entre o humano e o instintivo coíbe uma interpretação mais ampla desse encontro. Afinal, definir o homem apenas como "animal de uma voz" que muda seus pés no decorrer da vida é, no mínimo, reduzir a complexidade do problema. Como Carvalho pergunta, "invertendo a questão, é o Homem apenas um animal que anda com quatro pés pela manhã, dois ao meio dia e três à noite?". Se a resposta for positiva, "a resposta de Édipo é também a sua auto-condenação, pois se o homem é apenas isto, que importa matar o próprio pai e casar-se com a própria mãe?” (1985, p. 32).

Todavia, intérpretes mais recentes têm valorizado mais a estranheza do mito do que uma leitura que acomode esta figura à comum contraposição cultura/ natureza. Indo na contra-corrente do esforço freudiano em alocar o mito edipiano como "universal", Jean Joseph Goux, em Oedipus, Philosopher (1993), afirma que a Esfinge é uma mito não apenas estranho como também "paródico" do velho ritual de iniciação masculino. Enquanto neste, o jovem enfrenta fisicamente um monstro feminino, a Esfinge não apenas é "vencida" por Édipo por meio de um diálogo quanto ela própria é responsável por sua morte, não o herói.

Perto de Perseu, Jasão e Ulisses, entre outras figuras heróicas de potência física, Édipo é o "decifrador de enigmas", qualidade mais intelectiva do que física, que por outro lado é ironicamente incapaz de "decifrar o enigma de sua própria identidade". Ou seja, trata-se muito mais de um herói "atípico" e "singular", quando não uma "aberração" na estrutura iniciática tradicional, do que um exemplo modelar de comportamento heróico (1993, p. 8-19).

No centro desta "aberração" que é o próprio percurso de Édipo - não um percurso de "rito de passagem da juventude à vida adulta" e sim um percurso estático no qual ele sai da casa dos pais para voltar à casa dos pais, e ainda mais, ao leito da mãe - temos a Esfinge, que propõe enigmas ao invés de altercação e que finda com sua própria existência ao invés de ser "findada" pelo herói. Em vista disso, a Esfinge mais e mais se afasta de sua prodigiosa família feminina e monstruosa e transmuta-se, ela mesma, em enigma. Ademais, diferente de outras criaturas, ela fala e pode estabelecer um diálogo. Ademais, diferente de outros monstros, ela tem a capacidade de decidir sua sina, devorando jovens tolos ou jogando-se despenhadeiro abaixo, encerrando com sua própria existência.

No ensaio "O silêncio da Esfinge: o erro de Édipo e a redescoberta resposta ao enigma", Jane Connell articula estes e outros problemas ao afirmar que se trata de um silenciamento deste símbolo feminino e de um silenciamento não apenas nos século clássicos ou anteriores ao XIX e sua revalorização do mito, como também um sombreamento que persiste no século XX. Segundo Connell, no decorrer da história, a Esfinge não passou de um espelho a refletir a identidade, a cultura, a época e o lugar de seus intérpretes, em sua maioria, masculinos. Raramente sendo ela própria, tornou-se pai assassinado, mãe deflorada ou meia-irmã amaldiçoada de um herói perpetuador de incestos, dos quais ela é também fruto: conta-nos Hesíodo que a Esfinge nasceu dos divinos e monstruosos Equidna e seu filho Ortro (Teogonia, versos 306-332).

Entretanto, tal esforço de encontrar no mito qualquer significado que não o da própria Esfinge resulta não apenas num revelar como também num velar aquilo que a própria criatura poderia ser, fazer ou dizer. Sendo tudo, menos ela, a Esfinge foi condenada ao silêncio e é neste silêncio que ecoam não apenas equivocadas lei- 
turas pretensamente reveladoras como o próprio cerne das diferenças de gênero que permeiam e pervertem o transcurso da nossa cultura. Ao silenciar a Esfinge, não estaria Édipo silenciando a única possibilidade que ele mesmo teria de conhecer-se? Por sua vez, ao torná-la invisível - transformando-a em pai, mãe e irmã - não estariam os intérpretes errando o alvo, perdendo também a oportunidade de aprender de seus enigmas, de seus interditos, de seus segredos?

É nesse espaço de ação e reação, de ataque e fuga, de vitória e derrota, que se constitui a amarga e irônica - por que não trágica? - vitória de Édipo sobre a Esfinge. Ao fazer dialogar antropologia, mitologia, cultura e psicanálise, entremeadas por filosofia, religião e arte, Connell desvenda o que fora velado numa história de silenciamento, cegueira, apatia e denegação. Ao responder à pergunta da Esfinge com "O Homem", não estariam os Édipos de todos os tempos afastando e coibindo a oportunidade rara e cara de um verdadeiro diálogo? Não é isso que a Esfinge propõe, esse ser FEMININO e FALANTE? E se usamos as palavras em caixa alta é porque Connell nos obriga a atentar para algo que, se óbvio, não o foi a nenhum intérprete anterior.

Ao utilizar Freud, Hegel, Lévi-Strauss, Ovídio, Goux e Edmunds, entre outros autores, em sua maioria, masculinos, Connel tece em seu texto uma série de idas e vindas históricas e metafísicas que desnudam o esforço tão masculino e ocidental de vestir, velar, esconder uma diferença que, se não destroçada, foi silenciada no decorrer de séculos.

Neste caso, trata-se de perceber no silêncio da Esfinge não apenas o silenciamento de metade da raça humana, mas a tragédia decorrente a esse herói - masculino, branco, ocidental etc. - que, ao nunca deixar a casa do pai e o leito da mãe, recusa-se a crescer. Ao silenciar a Esfinge, ao ignorar sua voz, sua identidade, sua feminilidade e a resposta ambígua exigida de um enigma igualmente ambíguo, o herói fracassa, deturpa-se, condena-se, ironicamente, achando-se vitorioso. Segundo Connell, ao responder ao enigma com a resposta "homem",

Édipo estaria apenas parcialmente correto. Ele teria tanto passado quanto fracassado no teste. Como um teórico, estava indo razoavelmente bem, mas a cegueira de seu gênero impediu seu sucesso. Sua limitada resposta extirpou o feminino, ignorando a pista que estava diante de seus olhos - a voz humana da Esfinge. Para ele, as modalidades de locomoção e a capacidade de usar o simples complemento de uma muleta marcam adequadamente a todos nós como humanos. A voz, que ainda melhor nos diferenciaria das outras criaturas, foi ignorada, apesar da anomalia da criatura que estava diante dele. Linguagem, inteligência e vontade, qualidades que nos permitem refletir sobre o despertar da tirania da existência e com as quais tomamos nossa posição dentro da sociedade civil, não foram contempladas pela resposta de Édipo. $\mathrm{Na}$ medida em que a Esfinge confronta o herói, ela se posiciona como uma locutora e como uma criatura insurrecta dentro de uma transação tradicional, formulaica, altamente marcada pelo gênero. Esse mistério, inserido em um enigma maior, jaz nas conseqüências da política de gênero: esta molda o desafio que a Esfinge propõe ao jovem homem - um aspecto no qual Édipo não é sábio. Ela propõe a inclusão, a não exclusão, do sujeito civil feminino e adulto na formação da estrutura tradicional. Todavia, não foi ouvida e, talvez, ainda não tenha sido ouvida. (2013, p. 65-66)

Ecoando Edmunds e o poema de Muriel Rukeyser, "Private Life of the Sphinx", Connell se pergunta se a Esfinge ainda não estaria lá, às portas da cidade grega de Tebas, enigmática em discurso e em corpo, aguardando futuros Édipos. Talvez o decifrador demore ainda a chegar. Porém, depois da leitura de Connell, ele ao menos estará mais atento à voz e ao corpo de uma criatura que acima de tudo é feminina, muito mais do que monstruosa.

Nesse sentido, artistas, escritores e pensadores do século XIX estavam buscando justamente reinterpretar esse problema, sendo o mito da Esfinge uma encruzilhada entre uma versão tradicional e patriarcal, quando não misógina, ao problema do feminino, e um caminho ainda obscuro, porém importante ao crescimento social e cultural. As pinturas de Jean-Auguste Dominique Ingres (1780-1867) e Gustave Moreau (1826-1898) são um belo exemplo dessa oposição.

Em "Édipo e a Esfinge" (1808), temos um herói que não só responde como também pergunta, alocando à esfinge uma posição passiva e espectadora, diminuída 
às sombras coadjuvantes em relação a um herói masculino, protagonista de sua história, protagonista da história. A crítica tem destacado o fato do Édipo de Ingres ser um filho do iluminismo do século XVIII e da revolução francesa, com todas as suas aporias e contradições. Nesta tela, a Esfinge não é um problema, nem um enigma, sendo o herói o grande destaque.

Por sua vez, passadas as primeiras décadas do século XIX e as luzes oitocentistas começando a rarear com todos os seus confiantes conceitos e respostas, Moreau e os poetas e pintores simbolistas exemplificam o contrário desta ilusória certeza anterior. Nesta "Édipo e a Esfinge" (1864), ela é tão protagonista quanto Édipo e ambos estão enlaçados numa dança/abraço que também é sexual. Imersos no olhar um do outro, Édipo e a Esfinge se miram enquanto miram um ao outro. De monstruosa criatura híbrida, ctônica, natural, a Esfinge transmuta-se agora num ser que, apesar de espelho, possui também uma personalidade, que reflete não apenas o seu observar mas que expressa a sua própria reflexão a respeito de si mesma. Em outros termos, ao retirar a Esfinge das sombras as quais Ingres e outros, em texto e imagem, haviam-na alocado, Moreau a trouxe para o centro da sua pintura, para o centro da sua discussão.

Seguindo nesta mesma direção, outro importante artista da virada do século XIX para o XX parecia estava atento ao problema encerrado no modo como o ocidente representou suas Esfinges, monstruosas ou femininas, quando não monstruosas femininas. Falamos de Franz Von Stuck (1863-1928), pintor e escultor alemão que criou três versões diferentes para o tema. É à análise dessas três telas que nos ateremos a seguir.

\section{III}

Entre os imaginários discutidos por Dijkstra em seu livro, uma imagem comum é aquela que associa o feminino a figurações animalescas de carregadas projeções simbólicas. Segundo o autor, tanto na literatura quanto na pintura novecentista, "fantasias a respeito da aparência de mulheres como animais cresceram grandemente em aparições, variando de simples comparações ('graça felina') até elaboradas caracterizações psicológicas" (1986, p. 288). O livro de Dijkstra é um excelente anedotário da fantasmática envolvendo não apenas qualificações bestiais comumente associadas ao feminino (gatos, cães, serpentes e outras) como também da imagística da bestialidade que envolve personagens como Salambo, Eva e suas parcerias Mênades. Na visão de Dijkstra, ficaria evidente que muitos

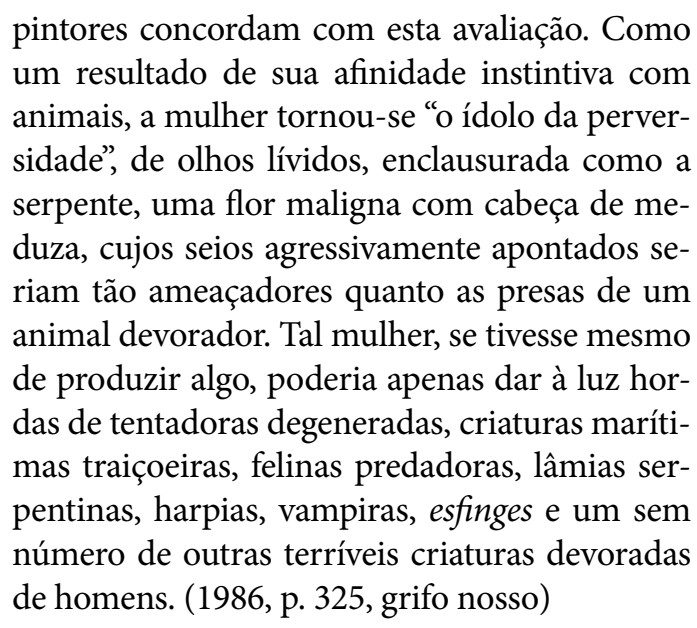

Aqui, obviamente, estranhamos a inserção da Esfinge neste grupo. Enquanto criatura que guarda o trono de Tebas contra possíveis usurpadores - apenas Édipo é o herdeiro legítimo, numa outra ironia presente no mito -, trata-se de uma presença monstruosa e enigmática, devoradora de homens, imaginário que a psicanálise fez questão de desconstruir e problematizar. Todavia, no que concerne ao encontro com Édipo, a Esfinge é mais vítima do que ameaça. E se pensarmos que a substituição de "devoradora" por "vítima" seria ir longe demais, podemos então atenuar a progressão apenas remetendo ao seu destino: diante de Édipo, a Esfinge tem seu segredo revelado, seu enigma des-coberto, seu diálogo interrompido. De devoradora de homens, passa não a monstro vencido, mas a criatura suicidas.

Assim, o que propomos a partir deste momento é a análise de três pinturas de Franz Von Stuck que podem nos dar subsídios para uma leitura diversa no que concerne à Esfinge. Diferente de Evas, Liliths, Salomés, Lâmias e Sereias, poderíamos encontrar na representação de seu corpo, de sua voz e de sua curta existência, uma alternativa à comum leitura desses seres míticos como meras extensões ao imaginário misógino comum ao século XIX.

Contemporâneo de Klimt, também um pintor de Esfinges - não tebanas, mas vienenses -, da literatura 
de Schniztler e dos escritos de Freud e Jung, o olhar de Franz Stuck sobre o feminino revela um misto de desconforto e fascínio, opondo figuras monstruosas a formas femininas tradicionais. Admirador da pintura simbolista de Arnold Böcklin, o artista dedicou-se a temas míticos e bíblicos num estilo considerado convencional, escolha que o tornou popular entre o público e nem tanto entre os críticos. Comentando sua Eva - pintura que ganhou, como a Esfinge, várias versões, sendo às vezes denominada de "Pecado" ou "Sensualidade" -, Dijkstra afirma que "Von Stuck tinha o hábito de repetir indefinidamente suas composições, na medida em que ávidos novos clientes exigiam novas imagens de mulheres malignas para pendurar em suas paredes como emblemas de advertência" (1986, p. 313).

Entre essas, está sua primeira interpretação para o tema da Esfinge, que ganhou no mesmo ano duas diferentes versões. A primeira, de 1889, apresenta uma moldura dourada, na qual o título anuncia a criatura mítica. Ao olhar do espectador, todavia, surpreende que o pintor apresente unicamente uma figura feminina e nua, deitada sobre a terra, tendo um paisagístico cenário natural disposto atrás da mulher. Nela, Stuck está apontando não apenas para a interpretação da Esfinge como símbolo feminino como também para a articulação deste com o ambiente natural.

A segunda versão amplia este escopo, ao articular duplamente o mistério da esfinge, equacionando o próprio enigma proposto a Édipo. Na porção inferior, apolínea e solar, que dramatiza o percurso da vida humana no fluxo de um ciclo diário, o enigma dos pés é apresentado na passagem da infância (quatro pés) à vida adulta (dois pés), e desta à velhice (três pés). É sabido que a resolução do enigma por parte do herói resulta numa vitória amarga e irônica, uma vez que ela não apenas o coloca no trono de Tebas como também no leito da rainha viúva. Ademais, o herói dos pés solucionar o enigma dos pés não nos parece tarefa tão difícil, como se a própria figura de Édipo já indicasse a resposta.

Stuck opõe a essa porção apolínea uma dionisíaca cena de escuridão noturna na qual, abaixo do título da obra, surge uma mulher nua, não uma criatura bestial e híbrida, mas uma dama que oferta sua nudez para ser desvendada pelo espectador. Nessa contraposição, o pintor parece sugerir que o verdadeiro enigma a ser solucionado seja justamente o do sujeito feminino. Como Camille Paglia articula, ao interpretar esta tela, é como se o pintor nos mostrasse "o homem" como "um sol poente eclipsado pela lua cheia da fatalidade feminina" (1990, p. 463);

Ironicamente, são contemporâneos da arte de Stuck os primeiros textos de Freud dedicados à histeria, moléstia a princípio considerada exclusivamente feminina. É ao observar esse mal-estar em suas pacientes que Freud pode não apenas formular uma reflexão clínica, como ironicamente dar um dos primeiros passos em direção a uma nova compreensão sobre a psicologia do homem ocidental. Ironicamente por ser também o mito de Édipo aquele que embasou suas primeiras considerações sobre a infância e o clássico entendimento freudiano do que o autor vienense chamou de "complexo edipiano".

Paglia interpreta a figura feminina dessas duas versões como uma esfinge "sinistra: uma feroz mulher nua estica-se num tapete como uma pantera, de barriga para baixo. A cabeça bonita, agressivamente inteligente, e o torso opulento imitam a postura alerta de uma Grande Esfinge masculina. Por trás dela, vê-se a estéril paisagem de Da Vinci, de rochas e água" (1990, p. 462). Neste sentido, parece-nos que o ponto central de Stuck é reapresentar o enigma feminino, menos maternal e mais sexual, a uma audiência já acostumada a esse tipo de representação.

Stuck não seria o único artista a utilizar-se do mito no período para referenciar ou reverenciar uma determinada visão do feminino. Klint, por exemplo, pinta suas damas como se todas elas fossem esfinges. Anos mais tarde, Léon Bakst, em "At Supper" (1901), apresenta uma mulher numa pose que não seria estranha a Stuck: num restaurante, com os braços estendidos sobre a mesa e o felino peito estufado, a enigmática dama da sociedade aguarda pelo jantar. Como Dijkstra afirma, o grande imaginário novecentista, "afinal, era o de que todas as mulheres eram Esfinges em seu coração" (1986, p. 325).

Em Stuck, todavia, o útero conectado à terra reforça a equação que associa feminino e natureza ctônica. Há um importante detalhe também no modo como o pintor altera a posição das mãos de sua personagem nas 
duas versões. Na primeira, na qual a dimensão da natureza é ressaltada, ela está conectada à terra, com os dedos tocando ou mesclando-se a ela. Na segunda, as palmas estão voltadas para cima, como se a aparição masculina a subjugasse a uma posição passiva, receptiva, imersa às sombras, recortada de seu cenário natural.

Além disso, a segunda versão também simboli$\mathrm{za}$ /ironiza a origem feminina do homem, sendo essa origem associada à mãe Gaia ou à mãe de todos nós. Alocar Stuck a porção masculino/apolínea abaixo e a feminina/dionisíaca acima, estabelece um interessante ponto de conexão entre o sol que paira sobre a existência humana e o útero de onde saímos, simbólico e artístico ou material e sexual.

Dois anos mais tarde, Stuck retornaria ao tema numa tela chamada "Édipo resolve o enigma da Esfinge" (1891). Nesta nova interpretação do mito, o pintor contrapõe a verticalidade escuro/claro ou dionisíaca/ apolínea, ou ainda masculino/feminino, a uma composição cujos contrastes horizontais apresentam o homem civilizado à esquerda, vestindo a toga dos juristas gregos e romanos, e o monstro feminino à direta, depositado sobre uma estrutura cavernosa escura e sombria.

Neste novo diálogo pictórico, a Esfinge é ainda sinal de morte, vide o crânio humano repousado ao lado da devoradora criatura e o ambiente sombrio e ctônico da qual é chamada. Esse chamamento é interessante, pois parece sugerir um esforço por parte do herói de retirar o monstro de sua obscuridade. Aqui, é como se Stuck tivesse representado aquilo que Connell interpreta nos seguintes termos décadas mais tarde:

Como o sangrento rito de iniciação foi traduzido em um encontro de angústia existencial, inexistia qualquer necessidade estrutural de o sujeito feminino não ser equivalente. Sófocles, em Édipo em Colono, reabilita Édipo após seu fracassado rito de passagem, dando-o outra chance: Mas por que não dar outra chance a ela? Se a Esfinge tivesse mais uma vez uma chance dela, evitando então a posição de víti$\mathrm{ma}$, isso lhe colocaria numa posição de maior responsabilidade, diminuindo um pouco a de Édipo. Neste caso, outras possibilidades poderiam ainda ser exploradas. Se ela e Édipo levassem adiante o seu diálogo, este poderia não ter superado a aporia entre os participantes, mas teria evidenciado a "universalidade" da importância de uma crise existencial. $\mathrm{O}$ fracasso diante do enigma demonstra a denegação generalizada diante da necessidade de uma crise como essa à maturidade masculina, feminina ou a de qualquer sujeito auto-reflexivo "diferente". Logicamente, este é um modelo melhor para a transição da adolescência à condição adulta do que a euforia passageira advinda do superficial triunfo sobre um outro objetificado. (2014, p. 70)

O que Connell está sugerindo e o que a pintura de Stuck pareceu dramatizar em 1891 é a necessidade de um princípio de diálogo entre o herói, confiante de sua veste cultural e das respostas certas para as (próprias) perguntas, em relação a uma alteridade corporal e também sentimental, figurada numa Esfinge assustadora porque assustada, temível senão temerosa. Suicidas, as Esfinges foram silenciadas por príncipes tebanos decifradores de todos os enigmas, exceto os próprios, que tinham a ver com origem e identidade. O Édipo de Stuck chamar a Esfinge da sua caverna e dos símbolos de monstruosidade, natureza e morte - imagísticas recorrentes na cultura e presentes na tela de 1891 - é sintomático de uma nova e bem-vinda compreensão do problema não apenas dos gêneros, como também das próprias crises individuais e subjetivas que formam a identidade do homem e da mulher ocidentais.

Ao término de um século XIX que começa com Édipos heroicos e iluminados, racionais e desbravadores, é a Esfinge que parece imergir na obra de poetas, romancistas, pintores e gravuristas como um problema cultural ainda não resolvido, como uma construção psíquica ainda permeada de rumores, segredos, meiasverdades ou verdades incompletas, mentiras veladas sussurradas por Édipos reticentes e inseguros diante de um corpo estranho e fascinante, não em virtude de sua feminilidade, mas em virtude de segredos ainda não desvendados. Quatro anos mais tarde, ao finalizar o seu metafórico tríptico dedicado ao tema da Esfinge, Stuck figuraria finalmente o encontro desses dois seres: agora não mais em eixos verticais assimétricos ou horizontais paralelos, e sim com um contato corporal, material e erótico que indicaria a via para a compreensão dos enigmas alheios e talvez de si próprio. 


\section{IV}

Na pintura de 1895, denominada "O beijo da Esfinge", a verticalidade retorna à composição do artista. Todavia, Stuck agora perverte inteiramente o mito opondo uma figuração sombria e ctônica à porção inferior, na qual se encontra o herói, e uma coloração avermelhada, erótica e vívida, à porção dominada pela Esfinge. Esta é ainda híbrida e monstruosa, porém altamente erotizada, ao mesmo tempo dominando e seduzindo o herói por meio de um apaixonado beijo. Ėdipo, quedado e vencido, é abraçado/aprisionado pelas patas leoninas da criatura. Seus braços, num dos elementos mais irônicos e bem-sucedidos da composição de Stuck, revelam a ambivalente relação do herói ocidental e suas esfinges: se um dos membros almeja escapar do enlace da criatura, o outro se entrega ao seu abraço e beijo, encerrando/aceitando o corpo da monstruosa figura com a mão esquerda.

As faces de ambos também articulam um ponto central à tela de Stuck. O rosto da Esfinge permanece nas sombras, indefinido e indefinível. Já o rosto de Édipo está parcialmente iluminado. Sabemos quase nada dela; conhecemos um pouco dele. Mas também este conhecimento é parcial. Ambos estão nus, como se as roupas e as máscaras sociais não mais importassem como elementos pertinentes na equação dessa relação. Nesta acepção, podemos sugerir que essa pintura é menos sobre as monstruosas esfinges e suas irmãs demoníacas e mais sobre uma reintegrada percepção masculina no que concerne ao mistério deste feminino. Desejaria Stuck aconselhar seus compradores, admiradores e críticos, a não mais tentarem desvendar segredos incapazes de serem completamente desvendados? Incentivando-os a, sábios como este Édipo morto $e$ renascido, entregarem-se ao mistério, ao beijo, aos segredos da Esfinge e a recusarem as respostas dos "falsos sábios" do seu tempo?

Somente agora, ao fitarmos essa relação, pela primeira vez inegavelmente sexual também - além de fatal, enigmática e natural, ou seja, conflituosa -, poderíamos então cogitar a possibilidade de um renovado diálogo. Connell afirma:
A resposta inadequada de Édipo ao enigma e o subsequente silêncio da Esfinge constituem um desperdício da possibilidade de reconhecimento. É o diálogo que demarcou uma possível saída deste persistente conflito, mas a capacidade deste herói para usar reflexão e linguagem a fim de escapar do ciclo de violência e opressão sexual era limitada. As tensões entre Édipo e a Esfinge oscilam entre a linguagem e a dispersão violenta dos corpos. Como um significante da diferença de gênero, a "voz" sugere o imaginário como problemática de gênero em relação ao discurso, para além da referência a sexo e violência por si mesmos. As mudanças de conteúdo dentro da linhagem do mito, a bifurcação da forma do próprio enigma e a perda de uma de suas respostas, todas elaboram as instabilidades deste tema - e do próprio percurso da civilização ocidental. (2013, p. 70-71)

É difícil parar de associar o feminino com algo ora relacionado à natureza ora aos elementos bestiais/animalescos reforçados por décadas de produção artística que tinham nesse imaginário seu principal tema. Num nível, Stuck pode estar fazendo seu herói assentir e entregar-se a esse imaginário. Num outro, todavia, o que ele parece diagnosticar é a submissão ao fascínio diante do mistério. Aqui, temos um herói nu e prostrado, cujo rosto está iluminado, abraçando uma representação ainda em sombras, ainda permeada de traços de ambiguidade e imprecisão.

No caso da leitura de Dijkstra, interessa percebermos o quanto ela denega a figura da Esfinge em sua dimensão de complexidade, ressaltando apenas seu caráter monstruoso, apesar de ressaltar que tal aspecto corresponda às representações comuns da fantasmática masculina dedicada ao feminino. Todavia, como o próprio autor afirma, em outra passagem de seu estudo, "a realidade raramente se enquadra no molde dualista", sendo este prova do "desespero que constrói absolutos (...), tornando as incoerências de ser no tolo paraíso das verdades incondicionais" (1986, p. 210). Segundo ele, o problema - e a complexidade - está, não no branco e no preto, no herói e no vilão, no bem e no mal, mas na problemática zona cinzenta na qual todos nós nos encontramos. A nosso ver, a Esfinge como mito, como símbolo, como problema, literário e pictórico, articula justamente esse entre lugar cinzento e complexo, entre 
a mulher pura e a mulher puta, entre a santa e a demoníaca, justamente aquilo que o livro de Dijkstra parece a todo o tempo buscar, mas raramente encontrar. Um exemplo disso é também sua análise do Beijo da Esfinge:

Entre outras associações do tipo, Fanz Von Stuck escolheu pintar uma Esfinge formidavelmente heterossexual - claramente uma criatura que nenhum ser humano masculino deveria ter qualquer contato, em primeiro lugar. Homens buscando alívio das tentações poderiam pendurar essa imagem em suas paredes, agradecendo ao empreendedor editor que publicou uma grande fotogravura desta obra prima atemporal feita sob medida para a moldura. Von Stuck tinha também o habito de pintar mulheres nuas em poses de esfinge sob o ar noturno, sob placas de mármore que claramente pertenciam a cemitérios. (1986, p. 325)

Assim, ao analisarmos os exemplos pictóricos acima, sejam os de Ingres, Moureau ou Stuck, será que ainda poderíamos dizer, como Dijkstra parece insistir com tanta ênfase, que "indiferente de como a Esfinge se apresente, ela certamente tem um feroz apetite por carnificina" (1986, p. 328)? Como todo grande artista, Stuck, ao lado de Gustave Moreau, utiliza a "iconografia da misoginia" para justamente evidenciar e atacar tal estrutura imperfeita, incompleta e, sobretudo, perversa no que concerne à alteridade feminina.

A nudez deste Édipo e desta Esfinge - nudezes que apontam para a nudez do nascimento e da morte e também, não esqueçamos, para a do sexo - ressalta a exclusão das vestes sociais, sejam elas iluministas, políticas, filosóficas ou psicanalíticas, todas vestes que cobrem o contato com o outro. Ora, velar o desvelado, cobrir o desnudo, como acontece com todos nos minutos seguintes ao nascimento, é sempre meta perigosa, sobretudo quando se compreende a si próprio como incompleto, ferido, infante ainda, ignorante da própria identidade. Édipo é um símbolo desta incerteza, deste homem que ainda não alcançou a maturidade, sendo seu encontro com a Esfinge o primeiro passo em direção a uma possível maturidade, fundamental à espécie, fundamental à cultura.

Todavia, abraçar a imprecisão, o híbrido e monstruoso corpo desconhecido, terra incognita, é jogar-se nos braços da incerteza, da dúvida, da ausência. Estas parecem justamente apontar para a fragmentação e para a incompletude deste herói ou desta versão do herói na modernidade tardia. Se até então Édipo saiu-se vitorioso - tolo que era, tolo que éramos - somente agora pôde aceitar sua derrota, prostrando-se diante do mistério que desejava - ilusão sua, ilusão nossa - solucionar. Ironicamente, e aqui estamos tratando do mito mais popular no que concerne à sua utilização pela tragédia, talvez seja a aceitação dessa derrota - da incompletude das respostas - a primeira grande vitória do homem ocidental em direção ao feminino mítico e a um corpo que sempre lhe pareceu estranho, singular, encantador enquanto perigoso, belo enquanto monstruoso.

\section{V}

Há, basicamente, duas relações possíveis entre os homens e suas esfinges. Primeiro, eles podem julgar decifrá-las, enredando-as e enredando-se em conceitos, respostas, definições, como boa parte da cultura fez. Segundo, podem aceitar seus enigmas como misteriosos e impossíveis de serem revelados, inescrutáveis enquanto equações de sexo e morte, de nascimento e finitude, de afirmação e aceitação. Curiosamente, tanto gregos do século V, contemporâneos dos trágicos, quanto pintores do século XIX, perceberam essa dupla dimensão, num movimento de Decifração e de Aceitação.

Quando Ingres pintou a sua versão do encontro de Édipo com a Esfinge, remeteu à primeira ideia, numa obra sintomática do iluminismo anterior e da visão de Hegel da Esfinge como uma natureza ainda não decifrada. Tanto o Édipo trágico quanto o herói de Ingres são homens de respostas, que tanto analisam, observam, refletem sobre esfinges estáticas e petrificadas quanto respondem aos seus mistérios. Ingres vai mais longe, ao alocar a pequena esfinge às sombras e ao fazer seu Édipo, fonte e receptáculo de luz, perguntar e responder ao enigma. Silenciada, emparedada e decifrada, cabe a ela expressar seu horror e sua fuga, movimento que Ingres dramatizou nas três versões da tela que produziu durante sua vida.

Moreau, outro artista obcecado por esfinges, escolheu a outra via. Sua versão mais famosa é a tela de 1867, 
pintura que o apresentou ao cenário artístico de Paris. Nesta tela, remeteu a uma cerâmica grega na qual a relação entre o herói e a criatura não era mais assimétrica no que concernia ao pensamento humano. Agora, o encontro era corpóreo, estando homem e esfinge imersos no olhar um do outro. A nudez de ambos - além do sutil encontro dos quadris - reforça um contato muito mais instintivo e físico do que intelectivo ou discursivo. Agora, o diálogo inexiste, dando lugar a um contato de olhares e de corpos.

Von Stuck, nas telas analisadas neste texto, coadunou leituras e interpretações em Esfinges que primeiramente são mulheres e que depois se transmutam em monstros saídos das cavernas naturais. Agora elas poderiam sair, porque as fissuras da lei e da cidade permitiram perceber uma dimensão selvagem e não domesticada fora dos limites de Tebas, uma dimensão que outrora aterrorizou os paradigmas da lei, da razão e da visão, Édipo e Penteu.

Mas tanto um quanto o outro foram cegados e despedaçados por sua visão do maternal corpo feminino. Édipo no leito de Jocasta. Penteu na dança báquica do Cíteron. Diferente desses, o Édipo de Stuck deixa de lado as certezas, as ilusões racionais, as vestes culturais, o desejo de ver/saber/definir. Trata-se de um herói que parece aceitar tudo o que vê, mesmo que de olhos bem fechados.

Diante dessa aceitação e diante do corpo da Esfinge, ele se ajoelha e se entrega, senão ao monstro, à dúvida, ao silêncio, à incerteza, de um corpo fascinante porque outro, de um toque perigoso porque desconhecido, de um beijo intenso e caloroso, mais de aceitação do que de dominação/nominação. Uma das mãos ainda se debate, pois é difícil desprezar o que os séculos ensinaram e petrificaram na consciência do ocidente. A outra, todavia, abraça o corpo feminino $e$ monstruoso porquanto outro, abraçando também um enigma não mais decifrado. Um enigma em tudo abraçado e acalentado, na profícua zona da dúvida e da não definição de uma alteridade que ainda nos é - e que talvez sempre será - estranha.

\section{Notes}

1. Exemplificam esse primeiro corpus pictórico centrado na representação do feminino as telas "Ophelia" (1851), de John Everett Millais, "The anatomist" (1869), de Gabriel Von Max, e "The crisis" (1891), de Frank Dicksee.

2. Veja as pinturas "Alma parens" (1883), de William Adolphe Bouguereau, "Nature" (1894), de Léon Frédéric, e "Leaf Drift" (1902), de Arthur Hacker, "Leaf Drift" (Corrego ou Pilha de Folhas), 1902, e a tardia, porém perfeita no seu emparelhamento do apolíneo masculino e do dionisíaco feminino, "The mountain mists" (1912), de Herbert Draper.

3. Veja as telas The remorse of Orestes" (1862) e "Nynphs and Satyr" (1873), de William-Adolphe Bouquereau", "Salome" (1871) e "The Apparition" (1875), de Gustave Moreau, "Meduza" (1878) e "Mermaids at Play" (1886), de Arnold Böcklin, "Sin" (1890) e "Adam and Eve" (1891), de Franz Von Stuck, "Nymphs dancing" (1895), de Johann Victor Krämer, "Bacchanale" (1896), de Lovis Corinth, "Lilith" (1892), de Kenyon Cox, "The temptation of St. Anthony" (1898), de Lovis Corinth, e "Ulysses and the Sirens" (1902), de Otto Greiner, entre dezenas de outras. Outra variação do mesmo tema são a de suplicantes figuras femininas nuas em contato com protegidos e piedosos cavalheiros masculinos, que recorrem aos "céus" por proteção contra a "ameaça feminina terrestre", em "Venus and Tannhauser" (1896), de Laurence Koe, e "The Knight" (1896), de Max Slevogt.

4. Para uma análise dessas idéias em Hegel, ver Silveira, 2000 e Gonçalves, sem data.

\section{Referências}

CARVALHO, S. M. S. “O Mito de Édipo - Uma Análise Antropológica”. In: BRANDÃO, J. L. (Org.) O Enigma em Édipo Rei e outros estudos de teatro antigo. Belo Horizonte: UFMG, 1984, p. 19-41.

COMMELIN, P. Nova Mitologia Grega e Romana. Belo Horizonte: Editora Itatiaia, 1983.

CONNELL, J. "O silêncio da Esfinge: O erro de Édipo e a redescoberta resposta ao enigma”. In: Fragmentum 38, Volume 2, 2013, p. 13-57.

DIJKSTRA, B. Idols of Perversity - Fantasies of Feminine Evil in Fin-de-Siecle Culture. Oxford: Oxford University Press, 1986.

EDMUNDS, L. The Sphinx in the Oedipus Legend. Hain, 1981.

GONÇALVES, M. C. F. "A Idéia de Corporalidade na Estética de Hegel". 
Disponível em: http://www.pgfil.uerj.br/pdf/publicacoes/ marciagoncalves/01.pdf. Acesso: 10 Março 2013.

GOUX, Jean-Joseph. Oedipus, Philosopher. Trad. Catherine Porter. Stanford: Stanford University Press, 1993.

HESÍODO. Teogonia / Trabalhos e Dias. Tradução de A. E. Pinheiro e J. R. Ferreira. Lisboa: Imprensa Nacional, 2005.

LÉVI-STRAUSS, C. Antropologia Estrutural. Rio de Janeiro: Edições Tempo Brasileiro, 1975.

PAGLIA, Camile. Personas Sexuais. São Paulo: Companhia das Letras, 1992.

RUKEYSER, M. "Private Life of the Sphinx". In: The Collected Poems of Muriel Rukeyser. New York: 1978, p. 278-9.

SEGAL, C. "The Music of the Sphinx: The Problema of Language in Oedipus Tyrannus." In: BLOOM, H. (Ed.) Sophocles' Oedipus Rex - Modern Critical Interpretations. New York: Chelsea House Publishers, 1988, p. 127-142.

SILVEIRA, R. A. T. "Édipo segundo Hegel". In: Revista Filósofos, v. 2, 2000, p. 127-143. Disponível em: www. revistas.ufg.br/index.php/philosophos/. $\quad$ Acesso: 10 Março 2013.

SÓFOCLES. A Triologia Tebana: Édipo Rei, Édipo em Colono, Antígona. Tradução e notas de Mário da Gama Kury. Rio de Janeiro: Zahar, 1990.

Recebido em: 22/04/2015

Aceito em: 23/07/2015 


\section{Figuras}

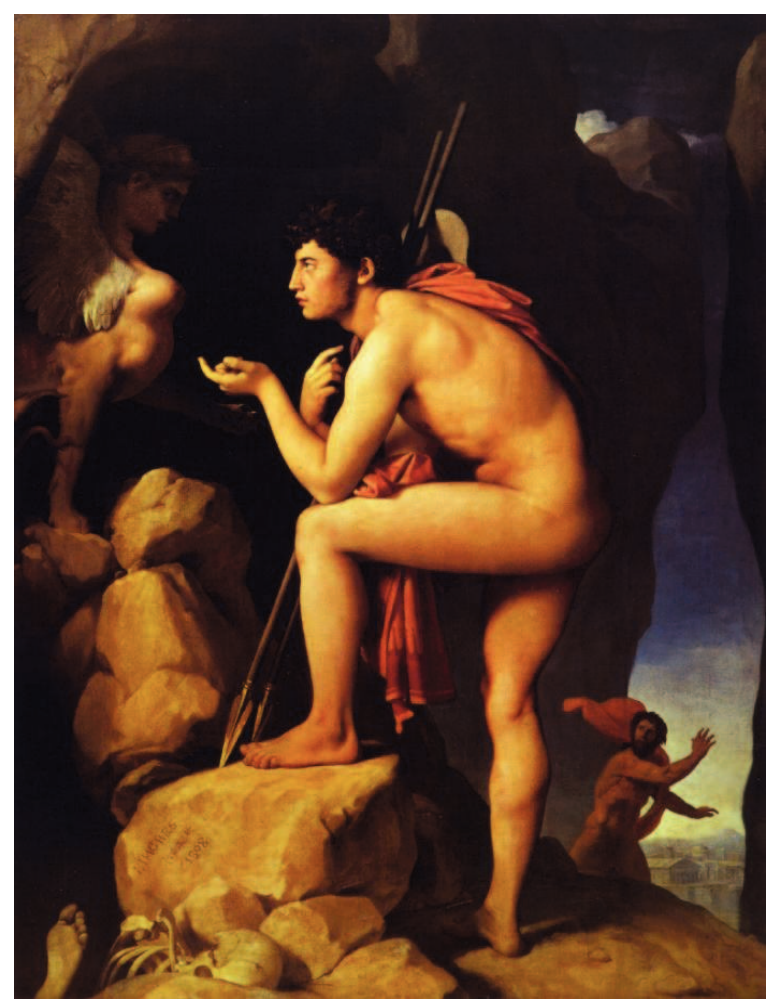

Fig. 1. J.-A. D. Ingres. "Édipo e a Esfinge", 1808, Óleo sobre tela, 189 x 144 cm, Paris, Louvre.

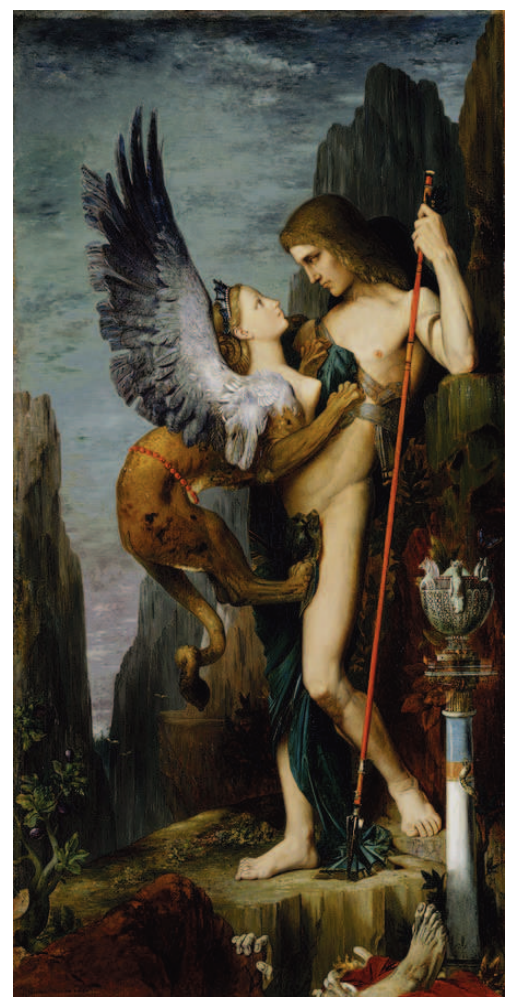

Fig. 2. G. Moreau. "Édipo e a Esfinge", 1864, Óleo sobre tela, 206 x 104 cm, New York, Metropolitan Museum.

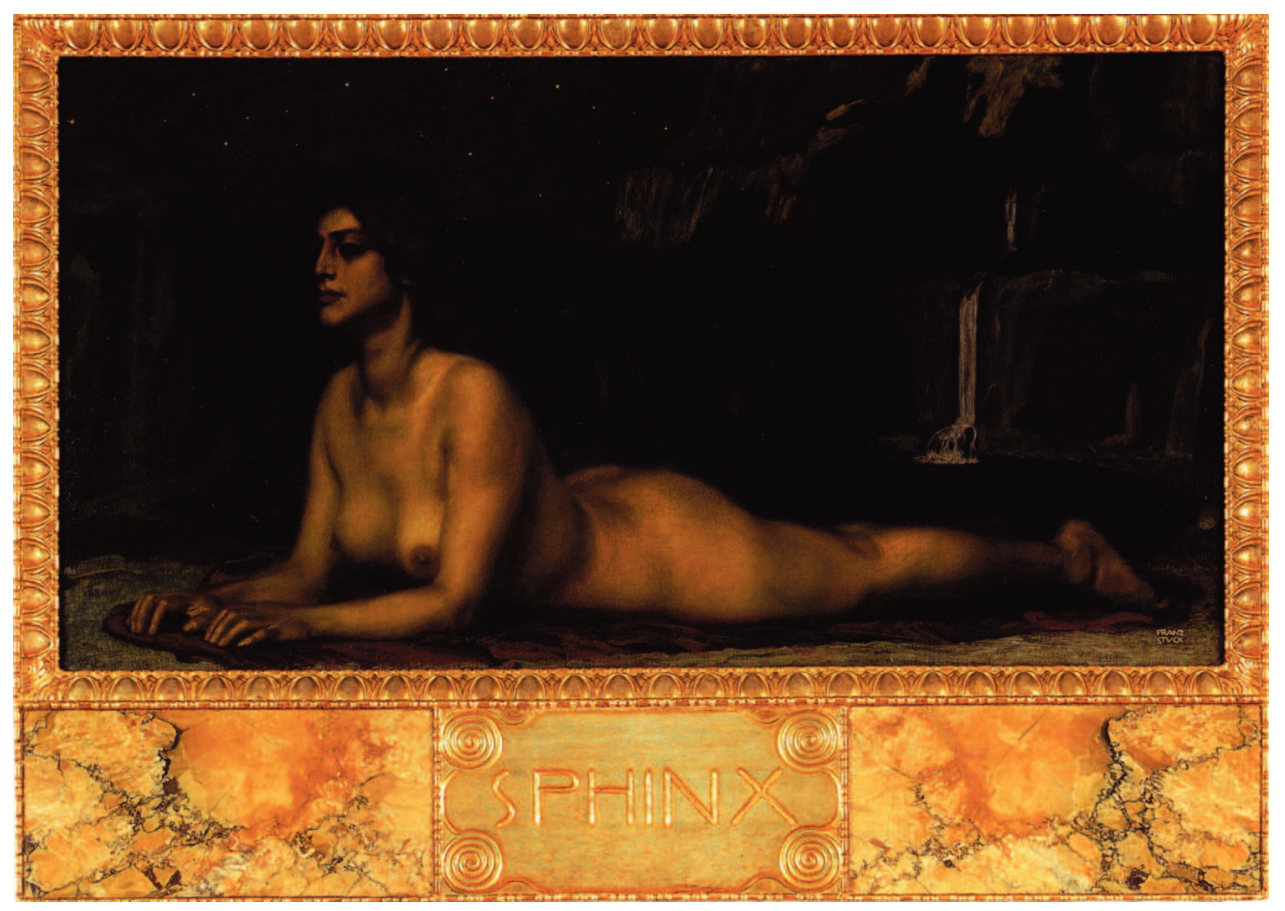

Fig. 3. F. Stuck. "Esfinge”, Primeira Versão, 1889, 83 x 157 cm, Óleo sobre Tela, Vila Stuck, Munique. 


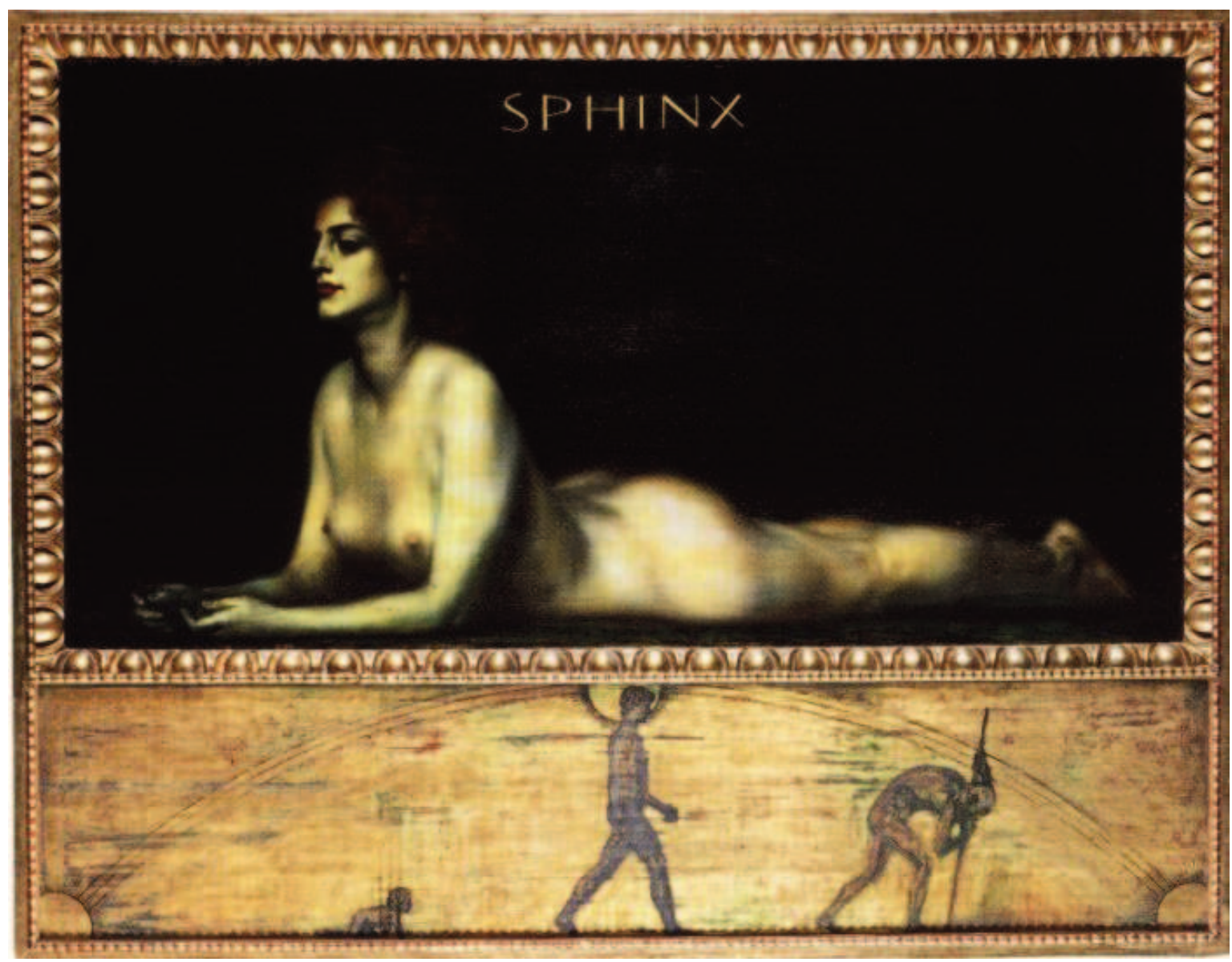

Fig. 4. F. Stuck. "Esfinge", Segunda Versão, 1889, Óleo sobre Tela, Coleção Particular.

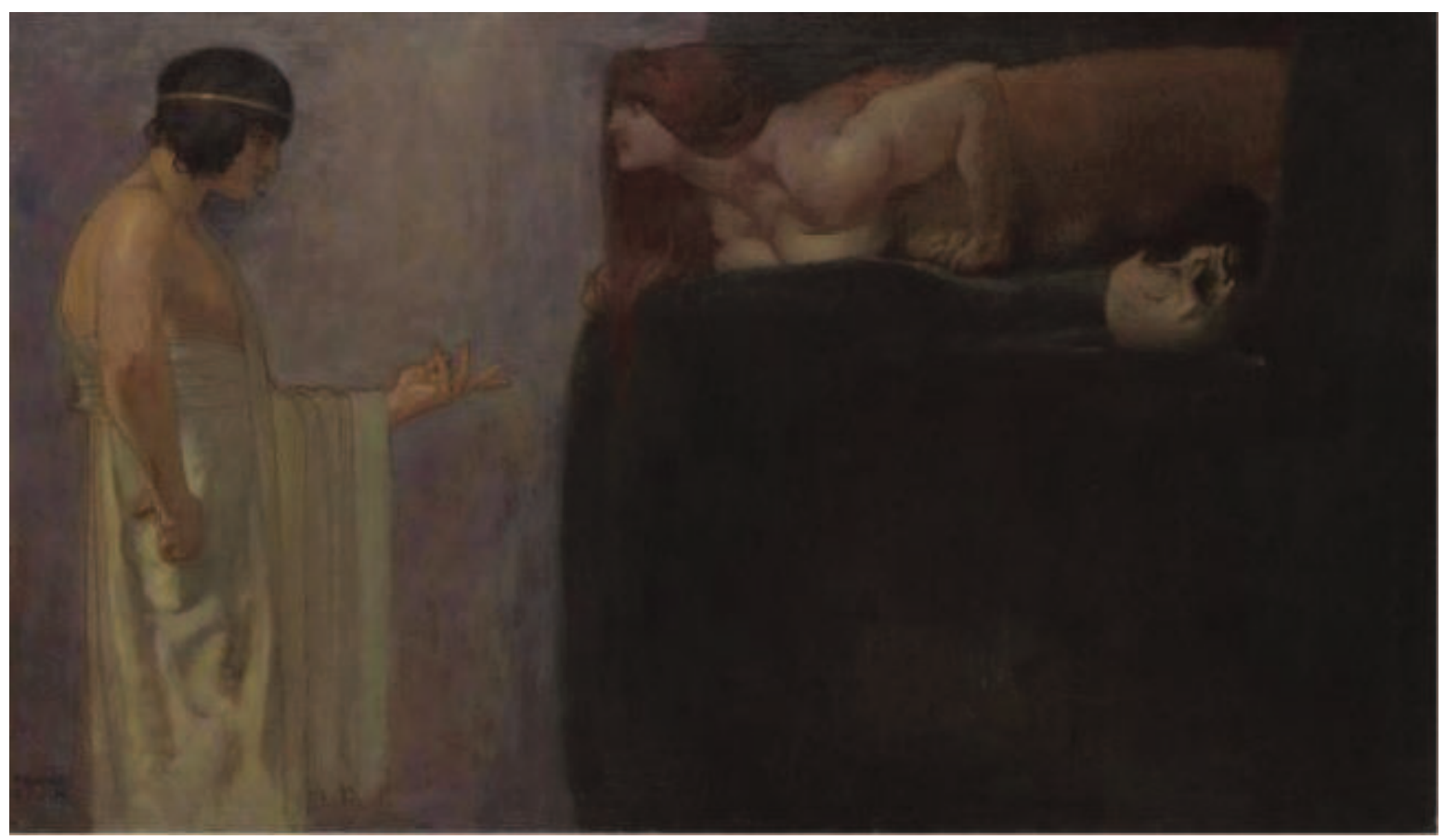

Fig. 5. F. Stuck. "Édipo resolve o Enigma da Esfinge", 1891, Coleção Particular. 


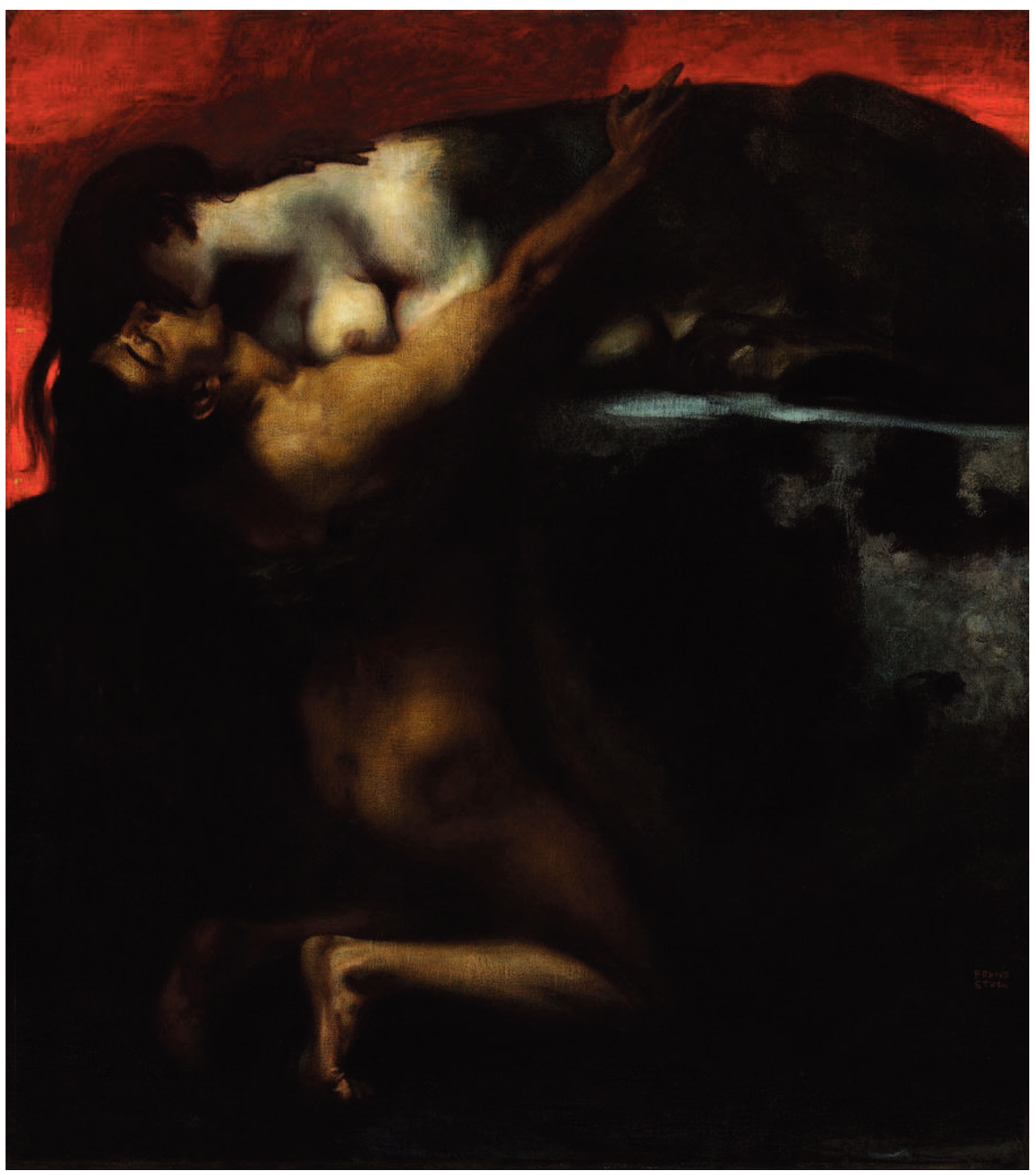

Fig. 6. F. Stuck. "O Beijo da Esfinge", 1895, 145 x 160 cm, Óleo sobre Tela, Budapeste, Museum of Fine Arts. 
